\title{
Safety study of the Bio-10-SAD Bern strain of the rabies virus on the rhesus macaque monkey species
}

\author{
Vladimír Vrzal \\ Bioveta, a.s., Ivanovice na Hané, Czech Republic
}

Received May 18, 2012

Accepted November 29, 2012

\begin{abstract}
Based on a WHO recommendation, residual pathogenicity of the Bio-10-SAD Bern rabies virus strain (component of the Lysvulpen por. ad us. vet. vaccine) was tested on rhesus macaque monkeys. Each of the ten monkeys, females, two years old, was administered orally $2 \mathrm{ml} \times 10^{9} \mathrm{TCID}_{50}$ of the Bio-10-SAD Bern rabies strain. The animals were monitored for 90 days. Subsequently, the animals were sacrificed and their brains were examined for presence of the vaccination rabies virus by the immunofluorescence and PCR methods. The occurrence of anti-rabies antibodies prior to and following administration of the vaccination rabies virus was also evaluated. No clinical signs of rabies were observed nor did any of the animals die of rabies following application of the virus. No rabies was detected in the study animals by post mortem examination. All of the 10 animals developed anti-rabies antibodies during the 90 days following administration of the rabies virus. It can be concluded, that Bio-10-SAD Bern virus administered at a dose equal to the tenfold maximum dose specified for field uses is safe to monkeys of the rhesus macaque species. This study is the first of its type performed in rhesus macaque monkey species.
\end{abstract}

Vaccine virus, oral administration, residual pathogenicity, autopsy, anti-rabies antibodies

Oral immunization of wild animals against rabies has become an integral part of the fight against this fatal disease both in Europe and in North America.

Any oral vaccine for immunization of wild animals should be efficient (i.e. cause protective immunity in the target animal species) and must be harmless to both the target and non-target animal species. Harmlessness is evaluated in the target animal species as well as in any other animal species (non-target species) that may come into contact with the vaccine following its distribution in the environment. The vaccine must not induce rabies in the animals nor propagate to animals sensitive to rabies through the animals vaccinated.

The World Health Organization (WHO 2005), the World Organization for Animal Health (OIE 2002, 2008), and European Pharmacopoeia (2007) have identified conditions and issued recommendations regarding requirements for vaccines intended for oral immunization of wild animals, to be met before the vaccines can be released for field uses. Blancou and Meslin (1996) recommend that a residual pathogenicity test be performed on monkeys.

The aim of this study was to verify the safety of the vaccination rabies virus strain Bio-10-SAD Bern in the rhesus macaque monkeys under good laboratory practice (GLP) conditions.

\section{Materials and Methods}

Bio-10-SAD Bern rabies virus strain

The Bio-10-SAD Bern strain of the rabies virus in the $1^{\text {st }}$ production passage (MSV +1$)$ was used in this study. The Bio-10 SAD Bern virus has its origin in the SAD Bern strain (vaccine strain used for immunization of

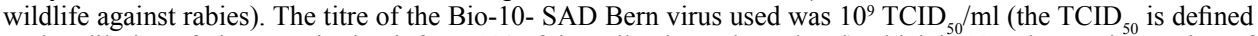
as that dilution of virus required to infect $50 \%$ of the cell cultures inoculated) which is $10 \times$ the maximum titre of the virus in the Lysvulpen por. ad us. vet. vaccine as used in the field for oral vaccination of wild animals against rabies.

Address for correspondence:

MVDr. Vladimír Vrzal, CSc.

Bioveta, a. s., Komenského 212

68323 Ivanovice na Hané

Czech Republic 


\section{Study animals}

The study animals included 10 female rhesus macaque monkeys (Macaca mulatta) from our own breeding facility Biotest Konárovice, 2 years old, 3.3 to $4.2 \mathrm{~kg}$ body weight, non-vaccinated against rabies, dewormed by Ivomec (Merial, France) at a dose of $0.2 \mathrm{mg}$ ivermectin per $1 \mathrm{~kg}$ of body weight prior to laboratory examination. The experiment was approved by the Ministry of Agriculture (No. 10984/2010-MZE-17210). The monkeys were placed individually in cages. Ambient temperature was $20-24{ }^{\circ} \mathrm{C}$, relative humidity $30-70 \%$; the ambient variables were monitored and recorded daily. The cages were cleaned twice a week, fresh water was given daily. The conditions included natural light. The monkeys were fed normal pelletized food for monkeys supplemented with fresh fruit or vegetables. The animals were allowed to acclimatize for 2 weeks in their cages prior to the administration of the virus. Following virus administration, each animal was kept in its cage for the entire trial period of 90 days.

\section{Administration of the virus, blood collection and taking of samples}

The Bio-10-SAD Bern viral strain was administered orally to the root of the tongue at amounts of $2.0 \mathrm{ml} \times 10^{9.0} \mathrm{TCID}_{50}$ (tenfold maximum field dose of the virus). No sedative drugs were administered. Each monkey was physically immobilized, a gag was inserted and after opening the monkey's mouth, the test virus was applied slowly by using a plastic syringe fitted with a rubber attachment in place of a needle. The monkey was observed swallowing the virus during the slow administration. Prior to the administration, the animals were weighed and blood was collected from them in order to measure anti-rabies antibodies in it. The monkeys were monitored on a daily basis with a focus on the occurrence of any clinical signs of rabies. The animals were weighed on a weekly basis. In the 90-day monitoring period, blood was collected again from all animals to measure antirabies antibodies in it, and then the animals were sacrificed by intravenous administration of pharmaceutical preparation T 61 (manufacturer Intervet International B.V., Netherlands) at a dose of $0.5 \mathrm{ml} / 1 \mathrm{~kg}$ of body weight. Samples of the cerebral cortex, cerebellum, medulla oblongata, and hippocampus were taken during the autopsy for assaying for rabies by the immunofluorescence and PCR methods.

\section{Biological samples examination}

Blood serum samples collected both prior to the trial and following the trial were assayed for the presence of anti-rabies antibodies by the Fluorescent Antibody Virus Neutralization test (FAVN) (C1 iqu e t et al. 1998).

Brain samples (cerebral cortex, cerebellum, medulla oblongata, and hippocampus) were examined for the presence of the rabies virus antigen by direct fluorescence method (Dean and Abelseth 1973).

The same brain samples (cerebral cortex, cerebellum, medulla oblongata, and hippocampus) were examined for the presence of the rabies virus antigen by Polymerase Chain Reaction (PCR) (Wakeley et al. 2005).

Total RNAs were isolated directly from $20 \%$ of brain tissue homogenates using BioRobot ${ }^{\mathbb{B}}$ M48 workstation and MagAttract Viral RNA M48 Kit as recommended by the manufacturer (Qiagen). RNAs were used as template in TaqMan one-step real-time RT-PCR using Qiagen One Step RT-PCR kit. For a single well $5.75 \mu 1$ RNase-free water, $5 \mu 15 \times$ reaction RT-PCR buffer, $1 \mu 1 \mathrm{dNTP} \operatorname{mix}(100 \mathrm{mM}), 6 \mu 1 \mathrm{MgCl}_{2}(25 \mathrm{mM}), 0.1 \mu 1$ RNAsin (Promega), $1 \mu \mathrm{l}$ enzyme mix, $0.2 \mu \mathrm{l}$ each of forward and reverse primers $(50 \mu \mathrm{M})$ and $0.25 \mu \mathrm{l}$ probe $\operatorname{mix}(30 \mu \mathrm{M})$ were used. Primers and probes used in the assay were published by Wakeley et al. 2005. Finally $5 \mu 1$ of RNAs were used at a total volume of $25 \mu 1$. RT-PCRs were carried out on iQ5 Cycler (BioRad). The following temperature profile was used: $30 \mathrm{~min}$ at $60^{\circ} \mathrm{C}$ (reverse transcription), $15 \mathrm{~min}$ at $95^{\circ} \mathrm{C}$ (inactivation reverse transcriptase / activation polymerase), followed by 45 cycles of $10 \mathrm{~s}$ at $95^{\circ} \mathrm{C}$ (denaturation), $45 \mathrm{~s}$ at $55^{\circ} \mathrm{C}$ (annealing) and $30 \mathrm{~s}$ at $72{ }^{\circ} \mathrm{C}$

Table 1. Antibody response in rhesus macaque monkeys after oral administration of the rabies vaccine virus strain Bio-10-SAD Bern by Fluorescent Antibody Virus Neutralization test

\begin{tabular}{cc}
\hline Animal No. & $\begin{array}{c}\text { Anti-rabies antibodies }(\mathrm{IU} / \mathrm{ml}) \\
\text { 3 months after the trial }\end{array}$ \\
\hline 1 & 7.8 \\
2 & 7.8 \\
3 & 1.5 \\
4 & $>40$ \\
5 & 5.0 \\
6 & 13.5 \\
7 & 1.5 \\
8 & $>40$ \\
9 & $>40$ \\
10 & 10.3 \\
\hline
\end{tabular}

(elongation). Fluorescence values were recorded during the annealing steps. For TaqMan real-time RT-PCR assay, a threshold cycle of SAD Bern virus with the titre $10^{7.63} \mathrm{TCID}_{50} / \mathrm{ml}$ used as positive control, was determined as equal to 22 .

\section{Results}

No deviations from normal physiological status and no signs of rabies were identified by daily monitoring of the 10 monkeys. All the samples (cerebral cortex, cerebellum, medulla oblongata and hippocampus) taken during autopsy after finishing the trial were negative for rabies virus when examined by both the direct fluorescence and the PCR method.

No antibodies were detected by the FAVN method in the animals prior to the 
trial. After finishing the trial, all 10 monkeys exhibited specific anti-rabies antibodies from $1.5 \mathrm{IU} / \mathrm{ml}$ to more than $40 \mathrm{IU} / \mathrm{ml}$ (Table 1$)$.

\section{Discussion}

Many European countries have been engaged in the project of oral vaccination of wild animals against rabies by using vaccines containing live attenuated rabies strains derived from the SAD strain, launched in 1978. The WHO issued a number of recommendations regarding the assessment of the innocuousness of oral vaccines (WHO 1989, 1992, 1992b, 1993, 1993 b, 1994, 1995, 1998). Nevertheless, the use of the vaccines is associated with some residual pathogenicity hazard posed by the SAD strain derivatives.

Residual pathogenicity in higher and other rodents was the subject of studies by Winkler et al. (1976), Wachendöfer et al. (1978), Steck et al. (1982), Leblois et al. (1988), Artois et al. (1992) and Vos et al. (1999). Wandeler (1988) described rabies in one fox cub, one cat and one stone marten following oral administration of the SAD Bern strain. Rupprecht (1990) reported rabies in 7 skunks out of 11 animals to whom the SAD B-19 vaccination virus had been administered per os.

Rabies was also found by Bingham et al. (1992) in 2 out of 4 Papio ursinus to whom the SAD Bern strain had been administered by oral route. One case of rabies in foxes following oral administration of the SAD B19 virus for immunization was observed in Austria (Vanek et al. 2004). Four foxes with rabies induced by the SAD B19 virus were found in Germany during the oral vaccination campaigns against rabies in 2001, 2002, 2004 and 2005 (Mueller et al. 2005). Sixteen cases of post-vaccination rabies were recorded in Canada in 1989-2004 in 4 red foxes, 2 raccoon dogs, 2 skunks and 1 calf among other animals (Brasilia RITA meeting 2006).

This hazard is, regrettably, also posed by new anti-rabies vaccines. The mutagenic rabies strain SAG 1 retains residual pathogenicity following intracerebral application to suckling mice (Schumacher et al. 1993). With the recombinant VRG rabies strain, skin lesions typical of smallpox developed in a young woman who had been bitten by a dog when trying to remove bait from the dog's mouth (Rupprecht et al. 2001).

The case of residual pathogenicity of the SAD Bern strain which, following oral administration of $2 \mathrm{ml}$ at a titre of $10^{7.5} \mathrm{TCID}_{50}$ to each of 4 baboons, induced fatal rabies in 2 baboons (incubation period 11 and 13 days) has been cited frequently in relation to the issue of residual pathogenicity of the SAD strain (Bingham et al. 1992). However, many aspects of this case are unclear. The precise inoculation of the virus in the oral cavity is not clear; the virus may have been applied into the nasal cavity, increasing susceptibility of the animals to rabies (the vaccination virus was applied to anaesthetized animals). Furthermore, the health condition of the animals is unknown, particularly as regards to their immune status (if animals had been immunosuppressed), their parasitic contamination, etc. No information exists regarding the stabling of the baboons, their feeding patterns, treatment, or other information relevant to the evaluation of the experiment. This is why we decided (also in line with the WHO recommendation) to reproduce the trial on a similar monkey species in rhesus macaque and on a larger group of animals $(n=10)$ in strictly objective conditions.

In contrast to the above-mentioned trial by Bingham et al. (1992) and the more recent trial by Vos et al. (1999), the monkeys in our experiment were not anaesthetized or sedated with any pharmaceutical drug. In fact, anaesthetization or sedation may cause incorrect application of the virus; the virus may get into the nasal cavities, in which it cannot enter in normal physiological conditions. This place is very prone to the induction of rabies. We administered the virus by means of a plastic syringe fitted with a rubber attachment. The monkeys were immobilized by the treating staff (the thoracic limbs were fixated behind 
the body, the head was held fixated by a nurse, and the mouth was kept open with a gag provided with an opening). The virus was administered through the opening in the gag to the root of the tongue by means of a plastic syringe fitted with a rubber attachment. Due to slow administration the monkey swallowed the virus, so the physiological effect was identical with that attained if the animal ate a bait with the virus within a natural immunization campaign. The fact that the virus got into contact with the immunocompetent organs (tonsils) was evidenced by the formation of specific virus neutralizing anti-rabies antibodies, observed in all animals in 3 months following the administration of the virus. The virus neutralizing anti-rabies antibodies were detected by using specific FAVN assay, whereby the titre of the specific anti-rabies antibodies could also be expressed in internationally recognized units.

No deviations from normal health status were observed in the animals during the 90-day monitoring period after administration of the virus. The test animals appeared absolutely healthy, they ate food very well with a good appetite and put on weight. Post mortem examination of the 4 parts of the brain that are very susceptible to rabies, i.e. the cerebral cortex, cerebellum, medulla oblongata, and hippocampus, using sensitive direct fluorescence assay and very sensitive PCR assay did not reveal rabies in any of the animals.

Administered at doses equal to tenfold the maximum dose specified for the target animal species, the Bio-10-SAD Bern strain of the rabies virus was absolutely harmless to the test specimens of monkeys of the rhesus macaque species.

\section{References}

Artois M, Guittre C, Thomas I, Leblois H, Brochier B, Barrat J 1992: Potential pathogenicity for rodents of vaccines intended for oral vaccination against rabies: a comparison. Vaccine 10: 524-528

Bingham J, Foggin CM, Gerber,H, Hill FWG, Kappeler A, King AA,Perry BD, Wandeler AI 1992: Pathogenicity of SAD rabies vaccine given orally in chacma baboons (Papio ursinus). Vet Rec 131: 55-56

Blancou J, Meslin FX 1996: Modified live-virus rabies vaccines for oral immunization of carnivores. In: Meslin FX, Kaplan MM, Koprowski H (Ed.): Laboratory techniques in rabies. World Health Organization, Geneva, pp. $324-337$

Cliquet F, Aubert M, Sangé L 1998 : Development of a fluorescent antibody virus neutralization test (FAVN test) for the quantitation of rabies - neutralizing antibody. J Immunol Methods 212: 79-87

Dean DJ, Abelseth MK 1973: The fluorescent antibody test. In: Kaplan MM, Koprowski H: Laboratory Techniques in Rabies, World Health Organization, Geneva, pp. 73-84

Eighth Report of the WHO Expert Committee on rabies (1992): WHO, Geneva

European Pharmacopoeia 2007: Vaccinum rabiei perorale vivum ad vulpem (live oral): 0746

Field application of oral rabies vaccines for dogs. WHO-OIE consultation, Geneva, 20-22 July 1998, Doc. WHO/ EMC/ZD/98.15, p. 24

Mueller T, Geue L, Kliemt J, Selhorst T, Frost J, Bunzenthal C, Zimmer K Vanek E, Revilla-Fernández S, McElhinney L, Fooks A: Vaccine associated rabies cases in Germany and Austria. RITA XVI, The 16th International conference on rabies in the America. Canada, October 16-21, 2005

Rabies chapter (2.1.13) of OIE Manual, 2008, oral vaccination paragraph

Report of the WHO Consultation on requirements and criteria for field trials on rabies vaccination of dogs and wild carnivores, Geneva, 1-2 March 1989, doc. EHO/Rab.Res./89-32

Report of the 3rd WHO Consultation on oral immunization of dogs against rabies, Geneva, 21-22 July, 1992, Doc WHO/Rab.Res./92.38

Report of the 4th WHO Consultation on oral immunization of dogs against rabies, Geneva, 14-15 June 1993, Doc. WHO/Rab.Res./94.42

Report of the 5th WHO Consultation on oral immunization of dogs against rabies, Geneva, 20-22 June 1994, Doc. WHO/Rab.Res./94.45

Report of the 6th WHO Consultation on oral immunization of dogs against rabies: , Geneva, 24-25 July 1995, Doc WHO/EMC/ZDI/98.13, p. 28

Rupprecht CE, Charlton KM, Artois M, Casey GA, Webster WA, Campbell JB, Lawson KF, Schneider LG 1990: Inffectiveness and comparative pathogenicity of attenuated rabies virus vaccines for the striped skunk (Mephitis mephitis). J Wildl Dis 26: 99-102

Rupprecht CE, Blass L, Smith K, Orciari LA, Niezgoda M, Whitfield SG, Gibbons RV, Guerra M, Hanlon CA 2001: Human infection due to recombinant vaccinia-rabies glycoprotein virus. New Engl J Med 345: $582-586$

Steck F, Wandeler A, Bischel P, Hafliger U, Schneider L 1982: Oral immunisation of foxes against rabies. Laboratory and field studies. Comp Immun Microbiol Infect Dis 5: 165-171 
The oral vaccination of foxes against rabies (2002): Report of the Scientific Committee on Animal Health and Animal Welfare, p. 55

Wakeley PR, Johnson N, McElhinney LM, Marston D, Sawyer J, Fooks AR 2005: Development of a real-time, TaqMan reverse transcription - PCR assay for detection and differentiation of lyssavirus genotypes 1,5 , and 6. J Clin Microbiol 43: 2786-2792

Vanek E, Wodak E, Revilla-Fernández S, Bagó Z, Schildorfer H, Hoeflechner A, Schoenbauer M 2004: Fox rabies in Carinthia, Austria: A case report. Rabies Bulletin Europe 28: 9

Vos A, Neuber, A, Aylan O, Schuster P, Pommerening E, Müller T, Chivatsi DC 1999: An update on safety studies of SAD B19 rabies virus vaccine in target and non-target species. Epidemiol Infect 123: 165-175

WHO/OIE Concertation meeting on rabies control in Europe, Piestany, 5-7 October 1993

WHO Expert Consultation on Rabies, OMS Geneva (2005): WHO Technical Report Series, n 931 , p. 87 